\title{
Note
}

[Agr. Biol. Chem., Vol. 33, No. 11, p. 1657 1658, 1969]

\section{Emulsifying Factor of Hydrocarbon Produced by a Hydrocarbon-Assimilating Yeast}

\author{
By Takashi Iguchi, Isao TAKeda and Hiroshi OHSAwa \\ Asahi Chemical Industry Co., Ltd., Asahimachi, Nobeokashi, Miyazaki
}

Received May 12, 1969

Hydrocarbon fermentation has been widely investigated by many researchers. Especially the production of single cell protein from hydrocarbons has become a matter of great interest in the world. The first step, in which microorganisms utillze the liquid hydrocarbons as carbon sources, will be emulsifying phonomena of hydrocarbon and water. The hydrocarbons, emulsified by microorganisms, may be absorbed easily into the cells.

We have recently found the hydrocarbonemulsifying factors produced into the cultural fluid by a hydrocarbon-utilizing yeast, Cadida petrophilum." One of these factors was isolated as a crude compound by ion exchange resin from the cultural fluid and showed the strong activity for emulsifying a mixture of hydrocarbon and water. This compound was named as "Emulsifying factor" This factor was composed of peptide and unidentified fatty acid. Glutamic acid, aspartic acid, alanine and leucine were identified after the hydrolysis of this factor with concentrated hydrochloride. Such a emulsifying factor seemes to play an important role in the assimilation of hydrocarbons by microoganisms.

TABLE 1. INFLUENCES OF THE SUPERNATANT OF BROTH ON THE EMUlStFication OF HYDROCARBON AND WATER

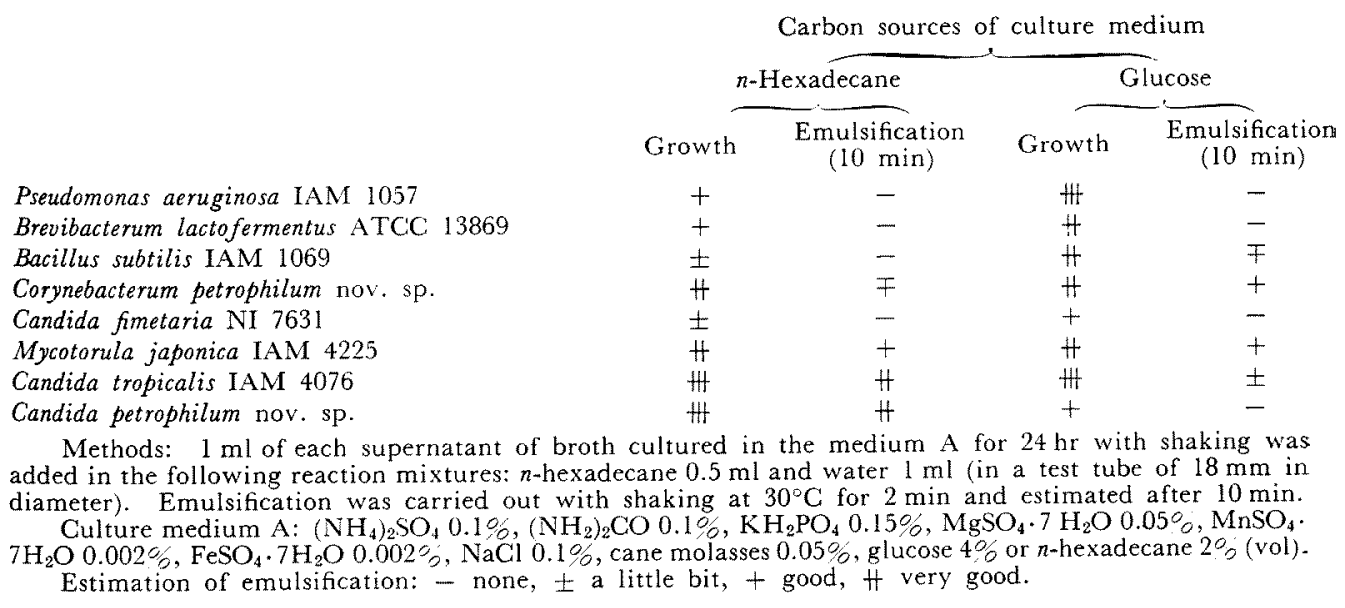

1) I. Takeda, T. Iguchi, T. Kawamura, S. Hayakawa and S. Senoh, Agr. Biol. Chem., 29, 796 (1965), 
Such a emulsifying factor is produced in a onsiderable amount in cultural broth. Most if hydrocarbon utilizing microorganisms tested re able to produce such a factor which mulsify a mixture of hydrocarbons and ultural fluid as shown in Table I.

Candida petrophilum was cultured in the lydrocarbon-medium described above and he supernatant after 2 days' culture was idded to the new medium in the same con:entration as described above. The growth ate of yeast was increased in proportion to he concentration of the cultural fluid. (Fig. 1)

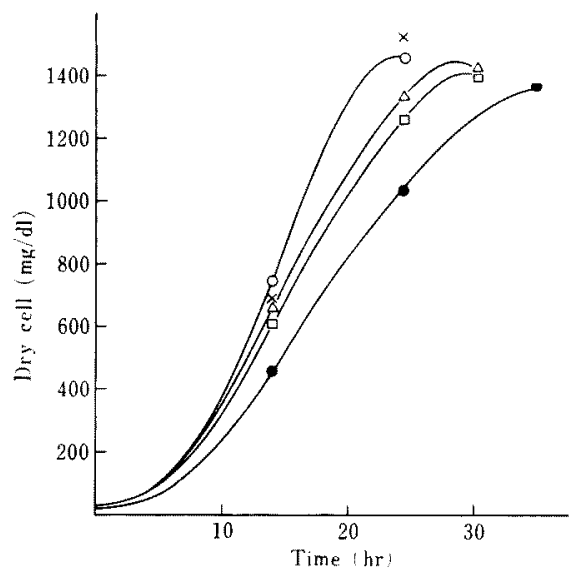

EIG. 1. Influence of the Supernatant of Broth on the Growth Rate of Yeast.

Basal medium: $n$-hexadecane $2 \%$ (vol), $\left(\mathrm{NH}_{2}\right)_{2} \mathrm{CO}$ $0.3 \%\left(\mathrm{NH}_{4}\right)_{2} \mathrm{SO}_{4} 0.1 \%, \mathrm{KH}_{2} \mathrm{PO}_{4} 0.15 \%, \mathrm{MgSO}_{4}$. $7 \mathrm{H}_{2} \mathrm{O} 0.05 \%, \mathrm{FeSO}_{4} \cdot 7 \mathrm{H}_{2} \mathrm{O} 0.004 \%, \mathrm{MnSO}_{4} \cdot 7 \mathrm{H}_{2} \mathrm{O}$ $0.004 \%, \mathrm{CaCl}_{2} 0.01 \%$, C.S. L. $0.1 \%$. The supernatant of 2 day old culture in the basal described above was added to the same medium as follows: $0-0$ cultural fluid $50 \%, \times-\times 25 \%$,

$\triangle-\triangle 10 \%, \square-\square 5 \%, \quad-00 \%$

'his phenomenon indicates the presence of naterials which stimulate the growth rate of east in the supernatant of 2 day old culture. Candida petrophilum was aerobically grown in ynthetic hydrocarbon-medium at $30^{\circ} \mathrm{C}$ for $0 \mathrm{hr}$ on a reciprocal shaker. After the centrifugation of the cells, the supernatant was passed through a column of Amberlite IRC $50\left(\mathrm{H}^{+}\right.$Type). The fractions having emulsifying activity were eluted with $50 \%$ solution of ethylalcohol from the above column and decolorized by passing an active charcoal column pretreated with ethylalcohol. An active component "Emulsifying factor" was obtained as a crude material by concentrating this eluate. The properties of an isolated compound which shows emulsifying activity were as follows. The ultraviolet absorption spectrum did not show any peaks (in alkaline solution) in the range of $230 \mathrm{~m} / t$ to $400 \mathrm{~m} \mu$. On the other hand, the presences of peptide bonds were demonstrated in infra-red spectrum (Fig. 2). Ninhydrin reaction of this

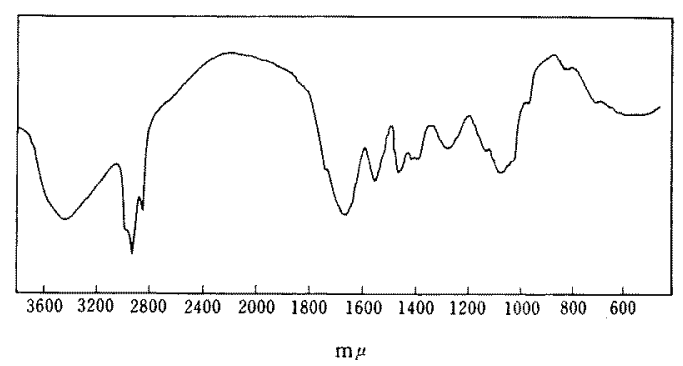

FIG. 2. Infrared Spectrum of Isolate Emulsifying Factor.

compound is negative. When emulsifying factor was subjected to acid hydrolysis in $6 \mathrm{~N}$ $\mathrm{HCl}$ in a sealed tube at $110^{\circ} \mathrm{C}$ for $20 \mathrm{hr}, \mathrm{L}$ aspartic acid, L-glutamic acid, L-alanine and L-leucine were detected by an amino acid analyzer and microbioassay. By the acid hydrolysis in $6 \mathrm{~N} \mathrm{HCl}$, a brown-colored, hydrochloric acid insoluble and oily material was liberated. This oily material was extracted with ether and showed the typical features of fatty acids in infra-red spectrum.

From these data, the emulsifying factor is confirmed to be composed of peptide and fatty acids. The crystallization of this crude compound and the identification of fatty acids are now in progress. 